\title{
Ibibio Causative and Anti-Causative Verb Alternations
}

\author{
Ogbonna Anyanwu \\ Department of Linguistics, University of Uyo \\ P.M.B. 1017, Uyo, Akwa Ibom State, Nigeria \\ E-mail: ogbonnaanyanwu@yaho.com
}

Received: June 3, 2012

Accepted: July 25, 2012

Published: August 1, 2012

doi:10.5430/elr.v1n2p25

URL: http://dx.doi.org/10.5430/elr.v1n2p25

\begin{abstract}
Causative and anti-causative verb alternations include the commonly attested cross-linguistic morphosyntactic phenomena and most languages have different ways of marking the alternations. Whereas in some languages, there is a clear morphological marking on the verb to indicate the causative/anti-causative distinction, in some others, there is no such morphological reflex or marker to indicate a verb's status with respect to causativity. This paper provides a descriptive analysis of causative and anti-causative verb alternations in Ibibio. Following the categorizations of Haspelmath's (1993) the paper highlights the two major ways by which the causative/anticausative verb alternation can be expressed in Ibibio. The first is through the directed (morphological) alternation, by which the distinction between the causative/anti-causative is indicated by a morphological reflex on the anti-causative verb. In Ibibio, the anticausative verb morphology can be expressed in three different ways; germinating the final consonant of the verb (root) of the lexical causative with a high tone vowel whose [ATR] value harmonizes with that of the final vowel of the root verb, suffixation (to causative verb root) of a harmonizing high tone vowel with a consequent weakening of the final consonant and by lengthening the first vowel of the causative verb root. The other option is the non-directed (lexical) alternation which is further divided into the suppletive and labile alternations (Haspelmath 1993). For the suppletive alternation, different verb roots are used for the causative/anti-causative alternations while the labile alternation is not yet observed in Ibibio The paper further observes that as has been noted in some languages, the anti-causative construction in Ibibio unlike its causative counterpart is characterized by a change in word order, absence of causative agentive noun phrase and an anti-causative affix (a morphological reflex of detransitivization and anti-causativization in the directed alternation. The data on which this study is based were collected from adult speakers of Ibibio by the author using an elicitation list. The database consists of acceptable words/expressions collected from standard Ibibio speakers within Uyo metropolis in Akwa Ibom, Nigeria.
\end{abstract}

Keywords: Causative, Anti-causative, Transitive, Intransitive, Agent, Patient, Lexical

\section{Introduction}

Causative and anticausative alternation include the range of widely studied phenomena in world languages, because "they are a source of great interest not only because of the important role they play in the derivational morphology of many languages, but also because of the way their analysis requires complex approach combining syntax, semantics and morphology" (Comrie 1985:323).A causative construction indicates that a subject agent/force causes some entity to do or become something, or causes a change in the state of a non-volitional event. Languages have ways of expressing causation, and may also differ in the means by which they do so. Depending on the contiguity of the elements encoding the causing event and that encoding the caused event, Comrie (1981) categorizes causatives into three main types which are: lexical, morphological and analytical (syntactic) causatives

\subsection{Lexical causatives}

Two events are expressed in a single lexical item. (The dog killed the rat vs. The rat died. Mary broke the plate. vs. The plate broke, John moved the stone vs The stone moved.) For verbs like break and move, Lyons (1968) notes that "the same verb enters into sentences of both causative and anticausative types without modification of the verb itself". Anderson (1977:116) has argued that the tokens of such verbs represent different underlying verbs, with different case specifications for NPs in constructions containing them.

Furthermore, for pairs such as kill vs die pair, Lyons (1968) states that they are pairs of different verbs between which the same syntactic (and semantic) relationship of causativity is "lexicalized" existing in corresponding 
intransitive and transitive sentences. The implication of this relationship is that kill is the lexical causative version of the anti-causative die and this is part of the lexical structure of English. Thus, the class of verbs in English and other languages to which kill belongs is also referred to as the class of lexical causative

\subsection{Morphological causatives}

The causing event and the caused event are encoded in a single verbal complex via causative morphology (e.g. Japanese kawak-asu 'make dry' (cf. kawaku 'become dry')) (Haspelmath 2008), Turkish _dör as in öl -dur- 'cause die'(cf. öl'die'), Swahili and Nivkh make use of the suffixes -ish and - $\boldsymbol{g u}$ respectively as in imb-ish 'sing cause' and cě-gu 'dry cause'(cf. imb 'sing' and cě 'dry intransitive' respectively. Also in Degema [Edoid; Benue Congo] (Kari 1995:158) the morphological type of causation is attested as shown in (i-iii) below.

1a) tu 'be burnt' $\rightarrow$ tu-ese 'cause to be burnt'.

1b) tul 'reach' $\rightarrow$ tul-ese 'cause to reach'

1c) kir 'return' $\rightarrow$ kir-ese 'cause to return'

A good number of languages have a morphological causative, a device for creating a verb form which means "to cause $\mathrm{x}$ to verb' from a form ' $\mathrm{x}$ verbs" (Spencer 1991). The additional morpheme to the already existing root morpheme expresses the idea of causation where ' $x$ ' is a variable which stands for the entity that gets the effect of the causation.

\subsection{Analytic (syntactic) causatives}

The causing event and the caused event are encoded in separate clauses ([X CAUSE [Y VERB]] (examples from English, John makes Mary laugh, Mary brought it about that Sam slide off the roof, Mary caused Sam to slide off the roof, Mary made Sam slide off the roof. (compare these with the anti-causative; Sam slide off the roof).

All languages seem to have lexical causative forms (as exemplified by the English kill $\rightarrow$ die). With respect to entities and relations that must be encoded in linguistic expression of causation, Shibatani (2001) notes that there must be an agent causing or forcing some other participant to perform an action, or to be in a certain condition and that the relation between the events (the causing event, and the caused performing/being event) is such that the speaker believes that the occurrence of one event, the caused event, has been realized at a later time after the time of the causing event.

Each type of causative construction will obviously have an anti-causative counterpart, a valency decreasing mechanism (Comrie 1985); an intransitive construction related to a transitive causative one. The term anticausativization refers to the intransitive use of a transitive verb where the original object, the undergoer, occurs as a subject. An anticausative verb is therefore an intransitively used verb that presents an event which affects its subject, without giving any semantic or syntactic indication of the cause of the event. The single argument of the anticausative verb (its subject) is a patient, that is, an experiencer. One can assume that there is a cause or an agent of causation, but the syntactic structure of the anticausative makes it unnatural or impossible to refer to it directly. Examples of anticausative verbs are the intransitive use of break, sink, move, etc. The anti-causative construction is similar in many ways to the passive; in both construction types, the direct object NP of the basic verb appears as the subject of anti-anti-causative or passive.

Ibibio attests the three major types of causative constructions; analytical (Ỏkón á-nám Ėnọ ásák imám, 'Okon made Eno laugh'), morphological and lexical causatives. In this paper however, our focus shall be on the Ibibio morphological and lexical causative/anti-causative verb alternations.

This paper is organized as follows: Section 2 provides an overview on causative and anti-causative verb alternation. Section 3 examines causative and anticausative verb alternations in Ibibio while section 4 is the conclusion.

\section{Causative and Anti-causative Verb Alternation}

The causative/anticausative alternation has provided an extensive platform for the study of the interface between lexical semantics, morphology, and syntax from a wide range of theoretical perspectives (Haspelmath 1993; Levin and Rappaport Hovav 1995; Wunderlich 1997; Hale and Keyser 2002; Baker 2003; Chierchia 2004). With respect the marking of the causative and anti-causative verb alternations, in some languages, there is a clear morphological marking on the verb to indicate the causative/anti-causative distinction, in some others, there is no such morphological reflex or marker to indicate a verb's status with respect to causative alternation. English show no change in the verb form of the intransitive member of the alternation, (i.e. lability proper), as in (1a), while in languages like Greek (1b) (Alexiadou \& Anagnostopolu 2004), and Italian (1c) (Folli 2002, Cennamo \& Jezek 2009) there are dedicated morphemes signaling anticausative status. 
1a) Mark broke the vase. $<$ The vase broke.

\section{1b) I supa kegete $\quad<$ O Janis ekapse ti supa}

the soup burns.NACT the John burnt.ACT the soup

'The soup is burning.' 'John burnt the soup.'

1c) Mario ruppe il vaso. $<$ Il vaso si ruppe.

Mario broke the vase the vase REFL broke

'Mario broke the vase' 'The vase broke.'

Two general semantic constraints on anticausativization have been recognized in the literature: They are (i) the spontaneous manifestation of an eventuality (Siewierska 1984) (ii) The absence of agent-oriented meaning components or other 'highly specific meaning components' that debar the spontaneous interpretation of the verbal process (Haspelmath 1987,1993). Thus, it is the case that only transitive causative verbs denoting events which happen spontaneously, without the intervention of an external willful animate causer, can occur in the anticausative alternation (Siewierska 1984, Haspelmath 1987). In most languages, the causative/anti-causative alternation is characterized by a change in word order and the absence of an agent NP in the anti-causative (inchoative) while the causative transitive form consists of an agent subject NP and theme object NP.

This paper contributes to the discussion on the typology of causative and anti-causative verb alternations with data from Ibibio. It is noted that the anti-causative construction in Ibibio unlike its causative counterpart is characterized by a change in word order and absence of causative agentive noun phrase Following Haspelmath's (1993), the two major ways by which the causative/anticausative verb alternation is expressed in Ibibio are highlighted; which can be through the directed (morphological) alternation. Here, the distinction between the causative/anti-causative is indicated by a morphological reflex on the anti-causative verb and non-directed (lexical) alternation: This is further divided into the suppletive; different verb roots are used for the causative/anti-causative alternations and the labile alternations; same verb occurs in both the causative and anti-causative alternations. Ibibio is spoken by about four million people (Essien, 1990) in fourteen (Uyo, Itu, Uruan, Etinan, Nsit Ibom, Nsit Atai, Nsit Ubium, Ibeskpo Asutan, Ikono, Ini, Ikot Abaasi, Mkat Enin, Ibiono Ibom, Onna and Eket ((Essien 1990, Urua 2007)) of the thirty-one Local Government Areas of Akwa Ibom State, Nigeria. More recent classifications have placed Ibibio in the Lower Cross group of the (New) Benue-Congo language family (Williamson, 1989).

\section{Ibibio Causative/Anti-Causative Verb Alternations}

The Ibibio language has a rich verbal morphology. As in other pro-drop languages, grammatical agreement holds between a lexical subject and a verb. In the anti-causative alternation, the undergoer of a change of state, which is lexically an internal argument externalizes, functioning as the grammatical subject. However, unlike in the passive structures, the causative agent does not become an oblique argument. In fact, it is not expressed overtly and it is probably the case that the pervasiveness of the anti-causative constructions in Ibibio is due to the fact that passives are not attested in the Ibibio grammar. Causative/Anti-Causative verb alternations in Ibibio can be directed (morphological) and non-directed (lexical). The non-directed (lexical) is further split into labile and suppletive alternations. These categorizations are discussed below.

\subsection{Directed (Morphological) Alternation}

Ibibio behaves like some languages (e.g. Russian, Nivkh, Spanish (and a sub-set of verbs in Turkish)) (Comrie 1985) in having an anti-causative morpheme. The distinction between the causative /anti-causative verb alternations is marked morphologically on the anti-causative alternation. That is, the causative verb is extended in the anti-causative by a verbal extension indicating absence of an agent (cf. Essien 1990). This verbal extension can be expressed in three different ways on the anti-causative verb morphology. First, this can be by germinating the final consonant of the verb (root) of the lexical causative with a high tone vowel whose [ATR] value harmonizes with that of the final vowel of the root verb. Without the anti-causative morpheme, the anti-causative construction will be ungrammatical $(1 \mathrm{c}, 2 \mathrm{c})$. Also a co-occurrence of the anti-causative morpheme with a substantive subject agent results in ungrammaticality $(1 \mathrm{~d} \& 2 \mathrm{~d})$ 
1a) éțìm á-máá-bôm èsìo

Etim 3sg.cl-past-break pot

'Etim broke the pot/Etim had broken the pot'

1 b) èsì̀ á-maa-bòmmó

pot 3sg.cl-past-break.ANTC.suff.

'The pot broke/The pot had broken'

1c) * èsì̀ á-bòm

pot 3sg.cl-break

1d) *étìm á-maa-bòmmó èsìò

2a) étìm á-wàk ợọ̀n ộmọ̀

Etim 3sg.cl-tear cloth his

'Etim has torn his cloths'

2b) ợộñ ọmọ̀ á-wàkká

cloth his 3sg.cl-tear.ANTC.suff.

'His clothes are torn'

2c) *ộộn ọmmô á-wàk

cloth his 3sg.cl-tear

2d)* étìm ọmọ̣ á-wàkká. ọfộn

3a) nkkòó á-máa-dúộk móọoọn

Nkoyo 3sg.cl-past-pour water

'Nkoyo poured water/Nkoyo had poured the water'

3b) ḿmọọọn á-maa-dúọ̀kkọ́

water 3sg.cl-past-pour.ANTC.suff.

'The water poured/The water was poured'

4a) ìnì à-máa-bún úbọ́k ọ̣mọ̀

Ini 3sg.cl-past-snapped hand his

'Ini broke his hand/Ini had broken his hand'

4b) úbọ́k ọmmộ á-máá-bún̄n̄ọ

hand his 3sg.cl-past-break.ANTC.suff.

'His hand broke/His hand was broken'

As can be observed from the examples, (1a-4a) are causative constructions, each with a volitive causative/agentive subject overtly expressed while the causative verbs are complemented by patient objects. In the anticausative constructions $(1 \mathrm{~b}, 2 \mathrm{~b}, 3 \mathrm{~b}, 4 \mathrm{~b})$ however, there is a morphological reflex of causativization attached to each verb stem; the causative agent is overtly absent while the patient has become the grammatical subject.

The second way of showing the morphological reflex on the anti-causative verb is through a suffixation of a harmonizing high tone vowel with a consequent weakening of the final consonant of the causative root verb. The following are some of the examples.
5a) údọ á-máá-bìat
àkèbbéndùsè
Udo 3sg.cl- past-spoil
television

'Udo spoiled the television/Udo had spoiled the television' 
5b) àkèbéńdùsè á-máá-bianá

television 3sg.cl-past-spoil.ANTC.suff.

'The television spoiled/The television was spoiled'

6a) éyọ̀ á-máá-tát údík

Eyo 3sg.cl-máá-untie rope

'Eyo untied the rope/Eyo had untied the rope'

6b) údík á-máá-tárá.

rope 3sg.cl-past-untie.ANTC.suff.

'The rope untied/The rope was untied'

7a) àsúkwọ́ á-máá-ýdd ús

Asukwo 3sg.cl-past-lock door

'Asukwo locked the door/Asukwo had locked the door'

7b) ús ín á-máá-ýré

door 3sg.cl-past-lock.ANTC.suff.

'The door locked/The door was locked'

8a) èmèm á-máá-sîid ús ún

Emem 3sg.cl-past-close road

'Emem closed the road/Emem had closed the road'

8b) ús

road 3sg.cl- past-close.ANTC.suff.

'The road closed/The road was closed'

9a) étìm á-máá-wựúk étó údiá

Etim 3sg.cl-past-erect stake yam

Etim erected a yam stake/Etim had erected a yam stake'

9b) étó údiá á-máá-wựúghọ

stake yam 3sg.cl-past-stand erect ANTC.suff.

The yam stake erected/The yam stake was erected'

10a) éyọ á-máá-siák ifiá

Eyo 3sg.cl-past-split firewood.

Eyo split the firewood/Eyo had split the wood'

10b) iffía á -máá-sìaghá

firewood 3sg.cl-past-split.ANTC.suff.

'The firewood split/The firewood was split' 
While (5a, 6a, 7a, 8a, 9a and 10a) are causative constructions with their respective overt syntactic agentive subjects, $(5 \mathrm{~b}, 6 \mathrm{~b}, 7 \mathrm{~b}, 8 \mathrm{~b}, 9 \mathrm{~b}$ and 10$)$ are their anti-causative counterparts with anti-causative morphological reflexes (-gha, gho, -re,-re -ra and -ra respectively). Again, the anticausative constructions do not have any syntactically active causers.

The third way by which the morphological reflex of anticausation in Ibibio can be expressed is by lengthening the first low tone vowel of the causative verb root. Thus, in this case, the anticausative morpheme is just a low tone vowel suffix which copies all the features of a preceding vowel of the causative verb stem as the following examples show (11b-14b).

11a) òkón á-máá-bèré úsún

Okon 3sg.cl-past-open door

'Okon opened the door/Okon had opened the door'

11b) úsún̄ á-máá-bèèré

door 3sg.cl-past-open

'The door opened/The door was opened'

12a) ifiọk á-máá-tọn̄ọ iộ́k

Ifiok 3sg. cl-past-begin race

'Ifiok began the race/Ifiok had begun the race'

12b) ìtok á-máá-tọòn̄ọ́

race 3 sg cl-past-begin

'The race began/The race was begun'

13a) 'imá á-máá-dòmmó 'ikán̄

Ima 3sg. cl-past-lit fire

'Ima lit the fire/Ima had lit the fire'

13 b) ikañ á-dòòmmó

fire $3 \mathrm{sg}$. cl-lit

'The fire lit/The fire was lit'

14a) ùdọ á-máá-nìmmé 'ikán

Udo 3sg.cl-past- put off fire.

'Udo put off/ quenched the fire/ /Udo had put off/quenched the fire'

14b) 'ikán á-máá-nìimmé

fire 3sg.cl-past put off

'The fire quenched/The fire was quenched'

As can be observed from (11b-14b) the low tone vowel anticausative morpheme eliminates the causative semantics (and causer argument) while retaining the change-of-state semantics. Other Independent principles of argument realization ensure that the hitherto patient argument raises to occupy the subject position in the absence of a causer agent. The directed morphological alternation is Ibibio is summarized in the table that follows. 


\begin{tabular}{|c|c|c|c|c|}
\hline $\mathrm{S} / \mathrm{N}$ & Causative (Transitive) & Gloss & Anticausative (Intransitive) & Gloss \\
\hline 1. & bôm & break & bòmmo & be broken \\
\hline 2. & Wàk & tear & wàkka & be torn \\
\hline 3. & dúọ̀k & pour & dúọ̀kkọ & be poured \\
\hline 4. & bún & snap & bún̄n̄ọ́ & be snapped \\
\hline 5. & bìát & spoil & bìárá & be spoilt \\
\hline 6 & tát & untie & tára & be untied \\
\hline 7. & yíd & lock & ýuré & be locked \\
\hline 8. & siid & close & sîire & be closed \\
\hline 9. & wúúk & stake & wúúgho & be staked \\
\hline 10. & sìak & Split & sìághá & be split \\
\hline 11. & bèré & Open & bèère & be opened \\
\hline 12. & tộn̄ọ & $\begin{array}{l}\text { begin } \\
\text { (a race) }\end{array}$ & tọộ̀nộ & be started \\
\hline 13. & dòmmó & light (fire) & dòòmmó & be lit \\
\hline 12 & nimme & put off (fire) & niīmmé & be extinguished \\
\hline
\end{tabular}

A summary of morphological directed alternation in Ibibio

\subsection{Non-Directed (Lexical) Alternations}

This is sub-divided into the labile and suppletive alternations. In Ibibio grammar however, it is only the suppletive alternation that has been observed yet, that is the labile option if attested in the grammar is not observed.

\subsubsection{Suppletive Alternation}

"The lexical causative type involves suppletion and there is no formal similarity between the basic verb and the causative counterpart" (Song 2001: 260). These are pairs of different verbs between which the same syntactic (and semantic) relationship of causativity holds in corresponding intransitive and transitive sentences. This phenomenon is however, quite common in languages. It is obvious that both the syntactic and semantic relationship existing between the transitive and the intransitive verbs can be said to be "lexicalized".

Example:

15a) ùdọ́ á-màá-wòt ébót

Udo 3sg.cl-past-kill goat

'Udo killed a goat/Udo had killed a goat'

15b) ébót á-máá kpá

goat 3sg. cl- PAST- die

'The goat died'

\section{Conclusion}

This paper has provided a description of causative and anti-causative verb alternation in Ibibio, thus, initiating interest and discussion in an aspect of Ibibio grammar that is yet to be given adequate attention. It has been observed that Ibibio anti-causative verb morphology can be expressed through the directed (morphological) alternation and the non-directed (lexical) alternation. It has been noted that the directed (morphological) alternation in Ibibio can be expressed in three ways (i) germinating the final consonant of the verb (root) of the lexical causative with a high tone vowel whose [ATR] value harmonizes with that of the final vowel of the root verb, (ii) suffixation (to causative verb root) of a harmonizing high tone vowel with a consequent weakening of the final consonant (iii) by lengthening the first vowel of the causative verb root. It is only the suppletive lexical alternation that is yet observed to be attested in 
Ibibio grammar.An aspect of the Ibibio alternation that deserves immediate examination is the direction of the alternation; whether it is from the causative to the anti-causative and vice versa.

\section{References}

Anderson, S. R. (1977). On mechanisms by which languages become ergative. In Li, C. N. (ed.) Mechanisms of syntactic change. ( pp.104-126) Austin: University of Texas Press.

Alexiadou, A. \& E. Anagnostopoulou. (2004). Voice morphology in the causative-inchoative alternation: Evidence for a non-unified structural analysis of unaccusatives. In A. Alexiadou, E. Anagnostopoulou \& M. Everaert (eds.). The Unaccusativity Puzzle: Explorations of the Syntax-Lexicon Interface (pp.123-159). Oxford: Oxford University Press.

Beavers, J. and Zubair, C. (2010). "Anticausatives in Sinhala: Involitility and Causer Suppression." Events and Sub-events, APS: Paris

Cennamo, M. \& E. Jezek. (2009). The anticausative alternation in Italian: constraints and variation. A paper presented at the Workshop on Verb Typologies Revisited: A Cross-linguistic Reflection on Verbs and Verb Classes, Gent, 5-7 February 2009.

Chierchia, G.. 2(004). A semantics for unaccusatives and its syntactic consequences. In A. Alexiadou, E. Anagnostopoulou, and M. Everaert (eds.) The unaccusativity puzzle (pp.22-59). Oxford: Oxford University Press.

Comrie, B. (1981). Language Universals and Linguistic Typology: Syntax and Morphology. p. 158-177. Chicago: University of Chicago Press.

Comrie, B. (1985). Causative verb formation and other verb-deriving morphology. In Shopen, T. (ed.). Language typology and syntactic description. Vol.3 (pp.309-348). Cambridge: Cambridge University Press.

Essien, O. E. 1990. A grammar of the Ibibio language. Ibadan, Nigeria: University Press Limited.

Folli, R. (2002). Constructing Telicity in English and Italian, PhD thesis. Oxford: University of Oxford.

Hale, K. L., and Samuel J. K. Prolegomenon to a theory of argument structure. Cambridge, MA: MIT

Press.

Haspelmath, M. (1987). Transitivity alternations of the anticausative type. Universität zu Köln (Arbeitspapiere N.F. 5).

Haspelmath, M. (1993). "More on the typology of inchoative/causative verb alternations." In: B. Comrie, and M. Polinsky, Maria (eds.) Causatives and transitivity.(pp.87-120) Amsterdam: Benjamins.

Kari, E.E. (1995). Extensional suffixes in Degema. Afrikanistische Arbeitspapiere. No. 44 (1995) pp. $149-168$.

Levin, B. \& Rappaport H. M.. (1995). Unaccusativity. Cambridge/MA: MIT Press.

Lyons, J. (1968). Introduction to theoretical linguistics. Cambridge: Cambridge University Press. http://dx.doi.org/10.1017/CBO9781139165570

Baker, M. C. (2003). Lexical categories: Verbs, nouns, and adjectives. Cambridge: Cambridge University Press. http://dx.doi.org/10.1017/CBO9780511615047

Pesetsky, D. (1995). Zero Syntax. Cambridge/Mass: MIT Press.

Siewierska, A. 1984. The Passive: A Comparative Linguistic Analysis. London: Croom Helm.

Shibatani, M. (ed.) (2001). The grammar of causation and interpersonal manipulation. Amsterdam and Philadelphia: John Benjamins

Song, J.J. (1996). Causatives and causation: A universal-typological perspective. London and New York: Addison Wesley Longman.

Song, J.J. (2001). Linguistic Typology: Morphology and Syntax. London: Pearson (Longman).

Spencer, A. 1991. Morphological theory: An introduction to word structure in generative grammar. Oxford : Basil Blackwell.

Urua, E. E. 2007. The tone system of Ibibio. Typology of African Prosodic Systems, 2001 Bielefeld Proceedings. Bielefeld, Germany. 65-85.

Williamson, K. (1989). Niger-Congo Overview. In J. T. Bendor-Samuel (ed.) The Niger- Congo Languages(pp.45=67). Lanham: University of America Press.

Wunderlich, D. (1997). Cause and the structure of verbs. Linguistic Inquiry 28.27-68. 